\title{
Characteristics of semen collected from the cauda epididymidis of conscious rams
}

\author{
J. K. Voglmayr, N. A. Musto†, S. K. Saksena, P. D. C. Brown- \\ Woodman*, P. B. Marley* and I. G. White* \\ Worcester Foundation for Experimental Biology, Shrewsbury, Massachusetts 01545, \\ U.S.A. and * Department of Veterinary Physiology, University of Sydney, Sydney, \\ New South Wales 2006, Australia
}

\begin{abstract}
Summary. A technique which permits collection of the total output of spermatozoa and fluid from the cauda epididymidis of conscious rams is described. The volume of epididymal semen collected varied in an approximately inverse proportion with the frequency of collection, but there was little variation in the concentration of spermatozoa. Chemical analyses showed that cell-free cauda epididymidis fluid contained lactic acid at various concentrations, only traces of glucose but relatively high amounts of phospholipid, pregnenolone, androgen-binding protein and $5 \alpha$-dihydrotestosterone $(5 \alpha-\mathrm{DHT})$.

Testicular spermatozoa maintained their metabolic activity and cellular integrity when stored in cauda epididymidis fluid in vitro at low temperature. After exposure to cauda epididymidis fluid for 14 days, testicular spermatozoa were predominantly glycolytic in their mode of glucose dissimilation and in this respect they resembled ejaculated spermatozoa.
\end{abstract}

\section{Introduction}

The caudal portion of the epididymis serves as a storage depot where mature spermatozoa are kept for various lengths of time, depending on the frequency of ejaculation. Conditions in the cauda epididymidis are obviously especially conducive to the survival of spermatozoa. In the rabbit, for example, the fertilizing ability of such spermatozoa is unaffected until they are 28 days old (Tesh $\&$ Glover, 1969). Understanding of these conditions in the cauda is obviously of paramount importance in the development of methods for the regulation of conception.

White, Larsen \& Wales (1959) collected semen from the cauda epididymidis of rams through the fistulated vas deferens, but this approach invariably caused losses of semen and increased the risk of bacterial contamination. An alternative method was subsequently introduced by Amann, Hokanson \& Almquist (1963) who obtained epididymal semen from bulls through the catheterized vas deferens. The problems with this preparation have already been described (Sexton, Amann \& Flipse, 1971; Voglmayr \& Amann, 1973). This technique has now been modified and extended to the ram to permit collections of the total output of spermatozoa and fluid from the cauda epididymidis.

\section{Materials and Methods}

\section{Animals}

Five entire rams (one Blackface, one Dorset and three Merinos; 3-6 years old) were housed in a barn where they were exposed to ambient temperature $\left(-5^{\circ} \mathrm{C}\right.$ to $\left.15^{\circ} \mathrm{C}\right)$ and $12 \mathrm{~h}$ light/day for at least 6 weeks before they were used. The animals were maintained on an unrestricted diet of hay, supple-

† Present address: M.S. Hershey Medical Center, Pennsylvania State University, Hershey, Pennsylvania, U.S.A. 
mented with $500 \mathrm{~g}$ of a mixture of oats and molasses per day. They were kept unrestrained except for the first 7 days after surgery when they were made to stand in metabolism cages. Shortly before surgery, ejaculated semen was collected twice from each ram by electrical stimulation (Blackshaw, 1954). With the exception of one ram, whose ejaculates contained a high percentage of immotile spermatozoa, the sperm concentrations, initial motility and percentage of abnormal spermatozoa were in the normal range for ram semen (Mattner \& Voglmayr, 1962).

\section{Collection and preparation of semen from the cauda epididymidis}

The catheter used for the collection of epididymal semen was made of seamless polyethylene tubing (i.d. $0.58 \mathrm{~mm}$, o.d. $0.96 \mathrm{~mm}$, length $16 \mathrm{~cm}$ : Clay Adams). Except for a $2.5 \mathrm{~cm}$-portion, the catheter was supported by Silastic tubing (i.d. $0.76 \mathrm{~mm}$, o.d. $1.65 \mathrm{~mm}$ : Dow Corning) which was swollen in toluene before use. After the toluene had evaporated, the Silastic tubing formed a tight sleeve around the catheter. A cuff ( $5 \mathrm{~mm}$ diam.) of Silastic adhesive (Silicone type A: Dow Corning) was placed at the proximal end of the sleeve, $2.5 \mathrm{~cm}$ from the tip of the catheter. The catheter was then reflected approximately $4 \mathrm{~cm}$ from the cuff to form a smooth loop filled with Silastic adhesive (Plate 1).

Under general anaesthesia (Fluothane: I.C.I.) and aseptic precautions the vas deferens was exposed through a $3 \mathrm{~cm}$-long incision near the midline on the anterior aspect of the neck of the scrotum and through the parietal tunica vaginalis immediately beneath the cutaneous incision. A $1.5 \mathrm{~cm}$-long portion of the vas was then carefully dissected out of its sheath without damaging the blood vessels. The sterilized catheter (Tego 103G: Goldschmidt A.G.) was inserted into the proximal end of the transected vas deferens which was secured to the cuff of the catheter by $4-0$ silk sutures. After placing the loop of the catheter between the spermatic cord and the internal spermatic fascia, the reflected part of the catheter was exteriorized through the incision on the anterior scrotum. The free end of the catheter was secured in the screw-cap of a 2 ml-capacity receptacle by placing a cuff of Silastic tubing (i.d. $1.02 \mathrm{~mm}$, o.d. $2 \cdot 16 \mathrm{~mm}$, length $1 \mathrm{~cm}$ ), swollen in toluene, around the catheter. The screw cap was attached to a hollow elbow of Silastic adhesive on Dacron mesh $(4 \times 5 \mathrm{~cm})$ which was affixed to the scrotum by heavy Vetafil (Bengen) sutures (Voglmayr, Kavanaugh, Griel \& Amann, 1972). The orifice of the catheter was occluded between collections by means of a modified Microgator clip (No. 34: Mueller, Cleveland).

Collections were made by palpating the cauda epididymidis for $10 \mathrm{~min}$. In some instances, electrical stimulation was also used (Blackshaw, 1954). The epididymal semen was diluted with 2-3 volumes of $0.9 \%(\mathrm{w} / \mathrm{v}) \mathrm{NaCl}$ solution. A small aliquot of the diluted semen was removed to assess the motility of the spermatozoa on a warm microscope stage and to determine the sperm concentration in a haemocytometer (Mattner \& Voglmayr, 1962). The spermatozoa were separated from the fluid within 20 min of collection by centrifugation in the cold $\left(2^{\circ} \mathrm{C}\right)$ at $2000 \mathrm{~g}$ for $20 \mathrm{~min}$ and the cell-free fluid was stored at $-20^{\circ} \mathrm{C}$ until used.

\section{Storage and incubation of testicular spermatozoa}

After semen had been collected for several weeks, the contralateral rete testis of 3 rams was catheterized to obtain testicular spermatozoa by the procedure described previously (Voglmayr, Scott, Setchell \& Waites, 1967). The testicular sperm suspensions were concentrated about 10 times by centrifugation at $200 \mathrm{~g}$ for $8 \mathrm{~min}$ in a sterile, graduated centrifuge tube of $12 \mathrm{ml}$ capacity. An aliquot of the concentrated sperm suspension was removed to assess the metabolic activity of 'freshly collected' testicular spermatozoa. The remaining sperm suspension $(0.5 \mathrm{ml})$ was mixed with an equal volume of either $0.9 \% \mathrm{NaCl}$ or cell-free fluid from the cauda epididymidis. The sperm suspensions were cooled over a $2-\mathrm{h}$ period and stored under air at $2-4^{\circ} \mathrm{C}$. On Days 4,8 and 12 of storage, $0 \cdot 2 \mathrm{ml}$ saline or epididymal fluid was added to the tubes as appropriate. After 14 days storage the sperm samples were equilibrated to room temperature. A small aliquot was used for the preparation of smears stained with nigrosin-eosin at $30^{\circ} \mathrm{C}$ for $5 \mathrm{~min}$ (Hancock, 1952). The percentage of dead and morphologically abnormal spermatozoa was determined from at least 500 counts/slide. The sperm- 


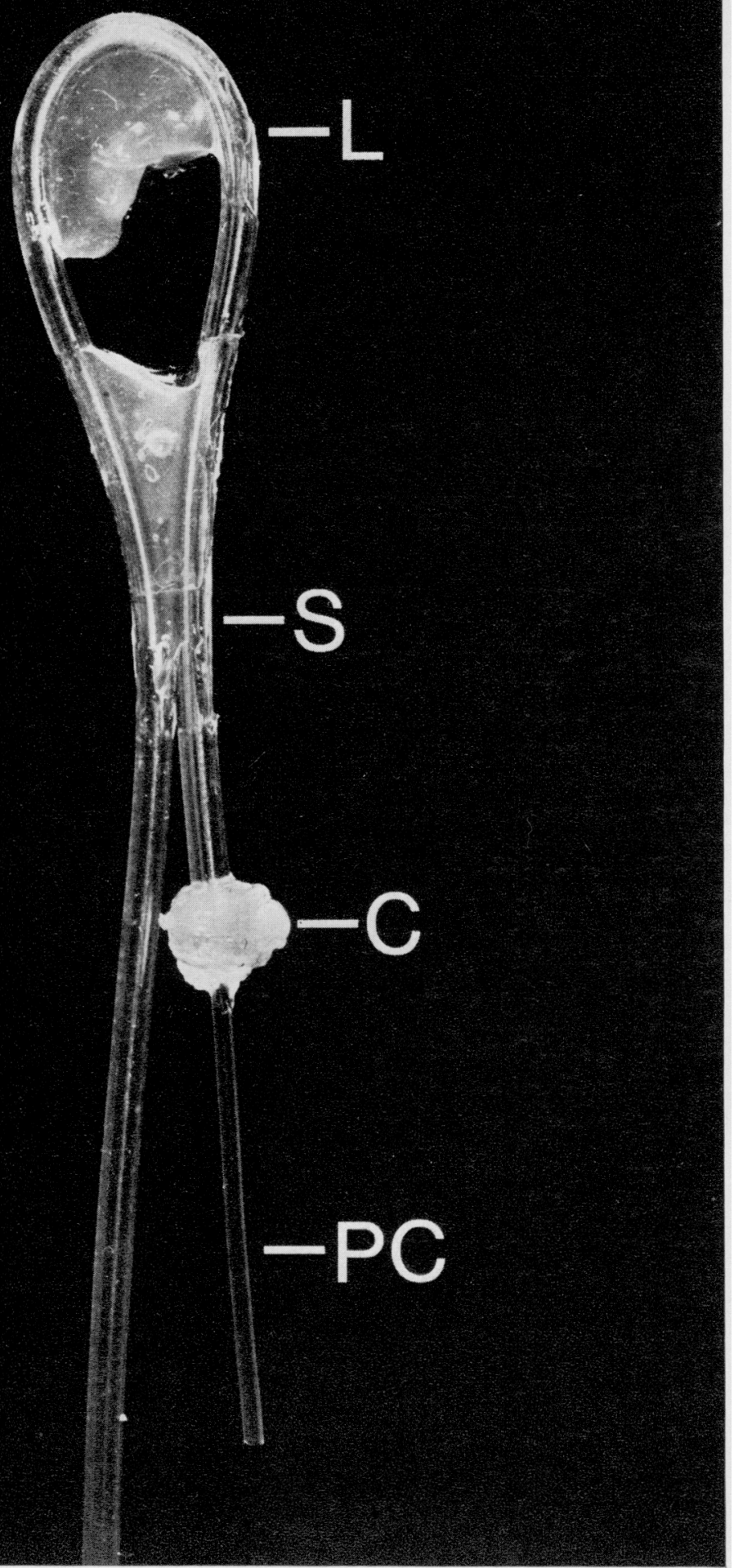


atozoa were washed twice (Voglmayr, Murdoch \& White, 1970) and then transferred into $7 \mathrm{ml}$ capacity Warburg flasks. The flasks contained $0.05 \mathrm{ml} \mathrm{20 \% (w/v)} \mathrm{KOH}$ on filter paper in the centre well and $0.5 \mu \mathrm{Ci}\left[\mathrm{U}-{ }^{14} \mathrm{C}\right.$ ]glucose (sp. act. $0 \cdot 1 \mu \mathrm{Ci} / \mu \mathrm{mol}$ : New England Nuclear) in the side-arm. After equilibration for $10 \mathrm{~min}$ the substrate was tipped into the sperm suspension and the reaction mixtures were incubated at $37^{\circ} \mathrm{C}$ for $2 \mathrm{~h}$ in a Gilson differential respirometer adjusted to a shaking rate of 60 cycles/min.

\section{Analytical procedures}

Oxygen uptake was measured by standard manometry at 30-min intervals. The glucose utilized and glucose oxidized or converted to lactic acid were calculated from ${ }^{14} \mathrm{C}$ radioactivity in $\mathrm{KOH}$ in the centre well or from radioassays and enzymatic estimations of the deproteinized suspending medium before and after incubation (Voglmayr et al., 1970).

Protein was measured with Folin phenol (Lowry, Rosebrough, Farr \& Randall, 1951) and glucose by the glucose oxidase method (Glucostat; Worthington Biochemical Company). Lactic acid was determined by the enzymatic method described by Barker \& Britton (1957) and free inositol by the biological assay method of Campling \& Nixon (1954). The concentrations of testosterone, androstenedione and dihydrotestosterone $(5 \alpha-\mathrm{DHT})$ were determined by radioimmunoassay (Saksena, Lau \& Chang, 1976) and pregnenolone by the procedure described by Purvis, Brenner, Landgren, Cekan \& Diczfalusy (1975). Androgen-binding protein was measured by the steady polyacrylamide gel electrophoresis technique of Ritzén, French, Weddington, Nayfeh \& Hansson (1974). The fluid from the cauda epididymidis was extracted for lipid with 50 volumes of chloroform-methanol $(2: 1 \mathrm{v} / \mathrm{v})$. The crude lipid extracts were purified as described by Scott, Voglmayr \& Setchell (1967) and the phospholipid concentration was calculated from the phospholipid phosphorus determined by the method of Fiske \& Subba Row (1925; lipid $=\mathbf{P} \times 25)$.

\section{Statistical analysis}

The results in Table 1 were subjected to analysis of variance. The significance between treatments was assessed by $t$ test using the interaction mean square from the analysis of variance to determine the standard error (S.E.M.) and the degree of freedom associated with it.

\section{Results}

\section{Composition of semen from the cauda epididymidis}

The mean volume of epididymal semen obtained from a single collection was $0 \cdot 86 \pm 0 \cdot 073$ (S.E.M.) $\mathrm{ml}$ (range 0.14-2.05) and it varied in an approximately inverse proportion with the frequency of collection (Text-fig. 1). There was little variation in the concentration of spermatozoa $(5.08 \pm 0.31 \times$ $10^{9}$ cells $/ \mathrm{ml}$ ) irrespective of the frequency of collection.

Inositol was present in cell-free epididymal fluid at a concentration of $179 \pm 3.96 \mu \mathrm{g} / \mathrm{ml}$. The fluid contained only traces of glucose but various amounts of lactic acid. In 4 rams, the mean concentration of lactic acid ranged from 8 to $101 \mu \mathrm{g} / \mathrm{ml}$ (mean of 5 replicates per ram), whereas in the fifth ram only trace amounts of lactic acid were detectable. In one ram, however, the lactic acid concentration in 2 of the 5 replicate samples exceeded $160 \mu \mathrm{g} / \mathrm{ml}$. Smears prepared with nigrosineosin showed that almost all of the spermatozoa from this animal were stained and tailless.

The mean concentration of total protein in the epididymal fluid was $19.3 \pm 1.61 \mathrm{mg} / \mathrm{ml}$. There were $79.9 \pm 18.7 \mathrm{pmol}$ androgen-binding protein $/ \mathrm{ml}$ fluid for 2 of the rams examined. The mean concentration of pregnenolone in epididymal fluid was $9.91 \pm 2.043 \mathrm{ng} / \mathrm{ml}$. In contrast, the concentration of pregnenolone in rete testis fluid of 3 rams used in the present study plus 2 other rams was only $0.85 \pm 0.144 \mathrm{ng} / \mathrm{ml}$ and that of peripheral blood plasma was $0.71 \pm 0.123 \mathrm{ng} / \mathrm{ml}$, i.e. $<10 \%$ the concentration in the cauda epididymidis. The mean levels of testosterone, $\Delta^{4}$-androstenedione 


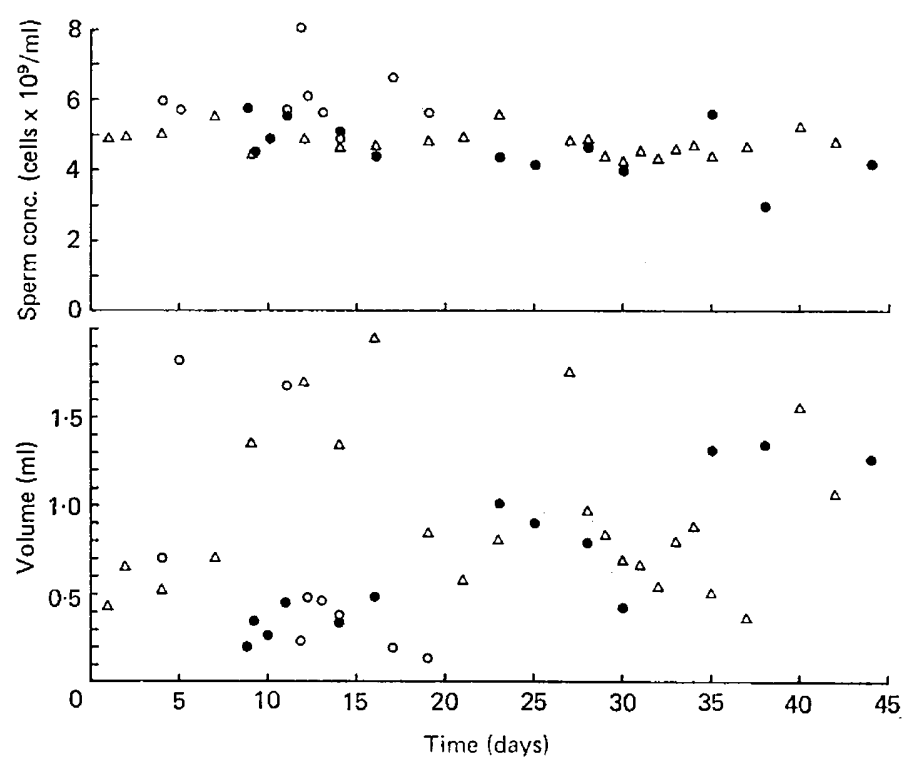

Text-fig 1. Volume and sperm concentration of ram semen from the cauda epididymidis obtained through the catheterized vas deferens. Symbols denote single observations from each of 3 rams. Note the relatively large volumes obtained at the first collection after a prolonged interval between collections, see e.g. Ram 2 (O) on Day 11 and Ram $3(\Delta)$ on Day 27-32. Epididymal semen from two other rams (not shown) was obtained for 103 and 136 days, respectively.

and $5 \alpha-D H T$ in the fluid from the cauda epididymidis were $2.58 \pm 0.86 \mathrm{ng} / \mathrm{ml}, 1.30 \pm 0.54 \mathrm{ng} / \mathrm{ml}$ and $16.93 \pm 4.97 \mathrm{ng} / \mathrm{ml}$, respectively. In the cauda epididymidis the concentration of total phospholipid was $1.34 \pm 0.127 \mathrm{mg} / \mathrm{ml}$, compared with only $0.042 \pm 0.005 \mathrm{mg} / \mathrm{ml}$ in the rete testis fluid.

\section{Effect of fluid from the cauda epididymidis on sperm survival}

Testicular spermatozoa stored in $0.9 \% \mathrm{NaCl}$ were markedly different, in morphology and metabolism, from testicular spermatozoa stored in epididymal fluid. As expected, the fluid from the cauda epididymidis had a beneficial effect on the metabolic activity and cellular integrity of the spermatozoa. The nigrosin-eosin mixture stained all of the testicular spermatozoa after storage with saline but only about $10 \%$ of the spermatozoa stored in epididymal fluid. The stained spermatozoa invariably displayed a disintegrating cytoplasmic droplet, which apparently lacked a cohesive outer membrane, but there was no change in the position of the cytoplasmic droplet or any significant development of motility in the spermatozoa under either condition of storage.

The oxygen uptake and utilization of glucose by testicular spermatozoa was much greater after storage in epididymal fluid than after storage in saline (Table 1). The glucose uptake of testicular spermatozoa exposed to the epididymal fluid tended to be higher than that of freshly collected testicular spermatozoa, but the relatively high coefficient of variation rendered these differences statistically insignificant. While the \% of utilized glucose converted to $\mathrm{CO}_{2}$ was similar for freshly collected testicular spermatozoa and spermatozoa stored in epididymal fluid, the latter accumulated a much greater proportion of the utilized glucose as extracellular lactic acid than the former. Thus, testicular spermatozoa after exposure to fluid from the cauda epididymidis were more dependent on exogenous glucose than were freshly collected testicular spermatozoa.

\section{Discussion}

The procedure which we have described for the collection of semen from the cauda epididymidis of conscious rams has greatly facilitated studies of the function of the epididymis. The catheters 
Table 1. Aerobic metabolism of $\left[\mathrm{U}^{14} \mathrm{C}\right]$ glucose by washed testicular spermatozoa of the ram after storage in $0.9 \%$ $\mathrm{NaCl}$ or cauda epididymidis fluid for 14 days

\begin{tabular}{|c|c|c|c|c|c|c|}
\hline \multirow{2}{*}{\multicolumn{2}{|c|}{ Treatment }} & \multirow[b]{2}{*}{$\begin{array}{l}\text { Oxygen } \\
\text { uptake } \\
\quad(\mu \mathrm{l})\end{array}$} & \multirow[b]{2}{*}{$\begin{array}{l}\text { Glucose } \\
\text { utilized } \\
(\mu \mathrm{mol})\end{array}$} & \multirow[b]{2}{*}{$\begin{array}{l}\text { Glucose } \\
\text { oxidized } \\
(\mu \mathrm{mol})\end{array}$} & \multicolumn{2}{|c|}{ Lactic acid accumulated } \\
\hline & & & & & $(\mu \mathrm{mol})$ & $\begin{array}{c}\% \text { of } \\
\text { of glucose } \\
\text { uptake }\end{array}$ \\
\hline (A) & $\begin{array}{l}\text { Freshly } \\
\text { collected }\end{array}$ & $30 \cdot 0$ & $0 \cdot 35$ & 0.063 & $0 \cdot 12$ & 34 \\
\hline (B) & $\begin{array}{l}\text { After storage } \\
\text { in } 0.9 \% \mathrm{NaCl}\end{array}$ & $19 \cdot 4$ & $0 \cdot 11$ & 0.009 & 0.06 & 54 \\
\hline (C) & $\begin{array}{l}\text { After storage } \\
\text { in epididymal } \\
\text { fluid }\end{array}$ & $35 \cdot 0^{*}$ & $0.50^{*}$ & $0 \cdot 102^{*}$ & $0.42^{* *}$ & 84 \\
\hline Star & ndard error & 3.88 & 0.061 & 0.0198 & 0.0101 & \\
\hline
\end{tabular}

Values are $/ 10^{8}$ spermatozoa and represent the means of 5 replicates.

* Different from B; $P<0.05$.

** Different from $A$ and $B ; P<0.05$.

remained patent for up to 136 days and abundant quantities of epididymal semen were collected under physiological conditions. The occlusion of the catheter between collections prevented losses of spermatozoa and fluid and eliminated the risks of bacterial contamination inherent in fistulated preparations.

The amount of epididymal semen $(0.86 \mathrm{ml})$ that can be obtained from a ram in a single day should be compared with the daily volume of up to $50 \mathrm{ml}$ fluid that transports spermatozoa out of the testis (Voglmayr, Waites \& Setchell, 1966) and the discrepancy between these volumes is indicative of the resorptive capacity of the epididymis. This selective fluid resorption also explains the marked increase in the concentration of spermatozoa as they are transported through the epididymal duct (Crabo \& Gustafsson, 1964). Comparisons with other rams showed that spermatozoa in the cauda epididymidis were about 75 times more concentrated than in rete testis fluid (Voglmayr et al., 1966; Setchell, Voglmayr \& Hinks, 1971).

The concentration of inositol in the cauda epididymidis is about $10 \%$ of the level normally found in rete testis fluid (Setchell, Dawson \& White, 1968; Setchell et al., 1971). Since the output of rete testis fluid per unit time ( $>120 \mathrm{mg} / \mathrm{ram} /$ day) exceeds many times the amount of fluid that emerges from the vas deferens $(0.2 \mathrm{mg} / \mathrm{ram} /$ day $)$, large quantities of inositol must be either resorbed or utilized by the epididymis. Differences of similar magnitude have already been observed in the bull but, although inositol is known to be utilized by epididymal tissue for synthesis of inositol-containing phospholipids, the significance of inositol uptake in such large quantities is obscure (Voglmayr \& Amann, 1973).

The origin of the lactic acid occurring in cauda epididymidis fluid is uncertain, but it may be derived from blood glucose. Allen \& Slater (1961) have demonstrated that lactic acid dehydrogenase is located in the apical portion of the epithelial cells lining the epididymal duct, with highest activity prevailing in the corpus and cauda portions. These workers suggested that the functional significance of the specific localization of lactic dehydrogenase lies in the secretion into the lumen of lactic acid. If this is true, lactic acid may serve as an important fuel for mammalian spermatozoa during epididymal transit.

The observed variation in the concentration of lactic acid in the cauda epididymidis might be explained by differences in the metabolic activity of the spermatozoa between samples and it might not be fortuitous that the concentration of lactic acid was highest in epididymal semen containing only few viable spermatozoa. However, it is also possible that manipulation of the cauda epididymidis during semen collection may have produced unusually high amounts of lactic acid in the smooth muscle layers surrounding the epididymal duct, thus contributing to the high lactic acid concentrations found in some samples of epididymal fluid. 
The fact that cauda epididymidis fluid contains pregnenolone at relatively high concentration is of particular interest in light of the steroidogenic capacity ascribed to epididymal tissue (Hamilton, 1971). The large pool of pregnenolone would provide a steady supply of precursor for steroid synthesis in the distal regions of the epididymis and could explain why the androgen level in the luminal fluid is much higher than that of peripheral blood plasma.

Androgen-binding protein in the epididymal fluid would also contribute to the high androgen environment, presumably through the concentrating mechanism proposed by Hansson, Ritzén, French \& Nayfeh (1975). The androgens that occur in the luminal fluid of the epididymis are unquestionably of importance for maintaining the functional activity of the epithelial lining of the excurrent duct, but they may also exert a direct influence on the spermatozoa (Fährmann \& Schuchardt, 1965; Skinner \& Rowson, 1968; Voglmayr, 1975). The level of 5 $\alpha$-DHT in the cauda epididymidis was found to be over 6 times the concentration of testosterone and this high ratio is consistent with previous observations on the rat and the bull showing that $5 \alpha$-DHT is the predominant androgen in the distal regions of the epididymis (Ganjam \& Amann, 1973; Vreeburg, 1975). Most of the 5a-DHT in cauda epididymidis fluid is apparently formed from testosterone by the epithelial cells lining the epididymal duct, but not by the spermatozoa since the latter do not possess the $5 \alpha$-steroid reductase activity required for the conversion (Vreeburg \& Scholte, 1973).

The presence of phospholipid at relatively high concentrations in the fluid from the cauda epididymidis may partly explain the ability of this fluid to prolong the life of the spermatozoa in vitro. For instance, certain phospholipids are known to be actively metabolized by ram spermatozoa obtained from any portion of the male reproductive tract (Scott, 1973). The presence of phospholipids in cauda epididymidis fluid would undoubtedly have a beneficial effect on the viability of the spermatozoa in vitro by providing substrate for metabolic energy and by protecting the spermatozoa against the damaging effects of low temperature storage (see Scott, 1973, for references). However, phospholipids, together with androgens and other as yet unidentified constituents of epididymal fluid, may also play an active role in promoting the 'maturation' of spermatozoa, and it is of particular interest that testicular spermatozoa, after exposure to cauda epididymidis fluid, utilize more glucose and convert a much greater proportion of the utilized glucose to lactic acid. After storage in the epididymal fluid the testicular spermatozoa do, in fact, become predominantly glycolytic in their mode of glucose dissimilation and in this respect they resemble ejaculated spermatozoa (Voglmayr, 1975).

This study was supported by Grant HD-09356 from the National Institute of Child Health and Human Development, National Institutes of Health, U.S. Public Health Service. The silicone rubber tubing used for the fabrication of the testicular catheters was a gift from Jehbco, Pty. Ltd, Brookvale, N.S.W.

\section{References}

Allen, J.M. \& Slater, J.J. (1961) A cytochemical analysis of the lactic dehydrogenase-diphosphopyridine nucleotide-diaphorase system in the epididymis of the mouse. J. Histochem. Cytochem. 9 , 221-233.

AmanN, R.P., Hokanson, J.F. \& Almquist, J.O. (1963) Cannulation of the bovine ductus deferens for quantitative recovery of epididymal spermatozoa. J. Reprod. Fert. 6, 65-69.

Barker, J.N. \& BrITTON, H.G. (1957) The enzymatic estimation of $\mathrm{L}(+)$ lactic acid. J. Physiol., Lond. 138, 3P-4P.

Blackshaw, A.W. (1954) A bipolar electrode for the production of ejaculation in sheep. Aust. vet. J. 30, 249-250.
Campling, J.D. \& Nixon, D.A. (1954) The inositol content of foetal blood and foetal fluids. J. Physiol., Lond. 126, 71-80.

Crabo, B. \& Gustafsson, B. (1964) Distribution of sodium and potassium and its relation to sperm concentration in the epididymal plasma of the bull. J. Reprod. Fert. 7, 337-345.

FährmaNN, W. \& SchuchardT, E. (1965) Elektronenmikroskopische Befunde am Epithel des Nebenhodenganges und des Samenleiters von normalen, hypophysektomierten und androgen behandelten Ratten. Naturwissenschaften 52, 212-213.

FISKe, C.H. \& SubBa Row, Y. (1925) The colorimetric determination of phosphorus. J. biol. Chem. 66, 375-400. 
GanJaM, V.K. \& Amann, R.P. (1973) Testosterone and dihydrotestosterone concentrations in fluid milieu of spermatozoa in the reproductive tract of the bull. Acta endocr., Copenh. 74, 186-200.

Hamilton, D.W. (1971) Steroid function in the mammalian epididymis. J. Reprod. Fert., Suppl. 13, 89-97.

HANCOCK, J.L. (1952) The morphology of bull spermatozoa. J. exp. Biol. 29, 445-453.

hansson, V., Ritzén, E.M., French, F.S. \& Nayfeh, S.N. (1975) Androgen transport and receptor mechanisms in testis and epididymis. In Handbook of Physiology, Male Reproductive System, Vol. 5, Chap. 7, pp. 173-201. Eds D. W. Hamilton \& R. O. Greep. American Physiological Society, Washington, D. C.

Lowry, O.H., Rosebrough, A., FARR, A.L. \& RANDALl, R.J. (1951) Protein measurement with the Folin phenol reagent. J. biol. Chem. 193, 265-275.

MATtNer, P.E. \& VoglmayR, J.K. (1962) A comparison of ram semen collected by the artificial vagina and by electro-ejaculation. Aust. J. exp. Agric. Anim. Husb. 2, 78-81.

Purvis, K., Brenner, P.F., Landgren, B.M., Cekan, Z. \& Diczfalusy, E. (1975) Indices of gonadal function in the human male. I. Plasma levels of unconjugated steroids and gonadotrophins under normal and pathological conditions. Clin. Endocr. 4, 237-246

Ritzé, E.M., French, F.S., Weddington, S.C., NAYFEH, S.N. \& HANSSON, V. (1974) Steroid binding in polyacrylamide gels: quantitation at steady state conditions. J. biol. Chem. 249, 6597-6604.

Saksena, S.K., LAU, I.F. \& Chang, M.C. (1976) The inhibition of the conversion of $5 \alpha$-testosterone into $5 \alpha$-dihydrotestosterone in the reproductive organs of the male rat. Steroids $27,751-757$.

Scotr, T.W. (1973) Lipid metabolism of spermatozoa. J. Reprod. Fert., Suppl. 18, 67-76.

Scotr, T.W., VoglmayR, J.K. \& Setchell, B.P. (1967) Lipid composition and metabolism in testicular and ejaculated ram spermatozoa. Biochem. J. 102, 456461

Setchell, B.P., DAWson, R.M.C. \& White, R.W. (1968) The high concentration of free myo-inositol in rete testis fluid from rams. J. Reprod. Fert. 17, 219220.

SeTCHell, B.P., VoglmaYr, J.K. \& Hinks, N.T. (1971) The effect of local heating on the flow and composition of rete testis fluid in the conscious ram. $J$. Reprod. Fert. 24, 81-89.
Sexton, T.J., Amann, R.P. \& Flipse, R.J. (1971) Free amino acids and protein in rete testis fluid, vas deferens plasma, accessory sex gland fluid and seminal plasma of the conscious bull. J. Dairy Sci. 54, $412-419$.

SkINNER, J.D. \& Rowson, L.E.A. (1968) Effects of testosterone injected retrogradely down the vas deferens on the accessory glands of the ram. $J$. Endocr. 42, 355-356.

TeSH, J.M. \& Glover, T.D. (1969) Ageing of rabbit spermatozoa in the male tract and its effect on fertility. J. Reprod. Fert. 20, 287-297.

VoglmaYR, J.K. (1975) Metabolic changes in spermatozoa during epididymal transit. In Handbook of Physiology, Male Reproductive System, Vol. 5, pp. 437-451. Eds D. W. Hamilton \& R. O. Greep. American Physiological Society, Washington, D.C.

VOGLMAYR, J.K. \& AMANN, R.P. (1973) The distribution of free myo-inositol in fluids, spermatozoa, and tissues of the bull genital tract and observations on its uptake by the rabbit epididymis. Biol. Reprod. 8 , 504-513.

VoglmayR, J.K., Wattes, G.M.H. \& Setchell, B.P. (1966) Studies on spermatozoa and fluid collected directly from the testis of the conscious ram. Nature, Lond. 210, 861-863.

Voglmayr, J.K., ScotT, T.W., Setchell, B.P. \& WAITES, G.M.H. (1967) Metabolism of testicular spermatozoa and characteristics of testicular fluid collected from conscious rams. J. Reprod. Fert. 14, 87-99.

Voglmayr, J.K., MURdoch, R.N. \& White, I.G. (1970) Metabolism of ram testicular spermatozoa in the presence of testosterone and related steroids. Acta endocr., Copenh. 65, 565-576.

Voglmayr, J.K., Kavanaugh, J.F., Griel, L.C., Jr \& AMANN, R.P. (1972) A modified technique for cannulating the rete testis of the bull. J. Reprod. Fert. 31, 291-294.

VREEBURG, J.T.M. (1975) Distribution of testosterone and $5 \alpha$-dihydrotestosterone in rat epididymis and their concentrations in efferent duct fluid. $J$. Endocr. 67, 203-210.

VReeburG, J.T.M. \& Scholte, H.R. (1973) Localization of $5 \alpha$-steroid reductase in the epididymis of the rat. Acta endocr., Copenh., Suppl. 177, 67.

White, I.G., LARSEN, L.H. \& WALES, R.G. (1959) Method for the in vivo collection of epididymal spermatozoa for their comparison with ejaculated cells. Fert. Steril. 10, 571-577.

Received 6 July 1976 